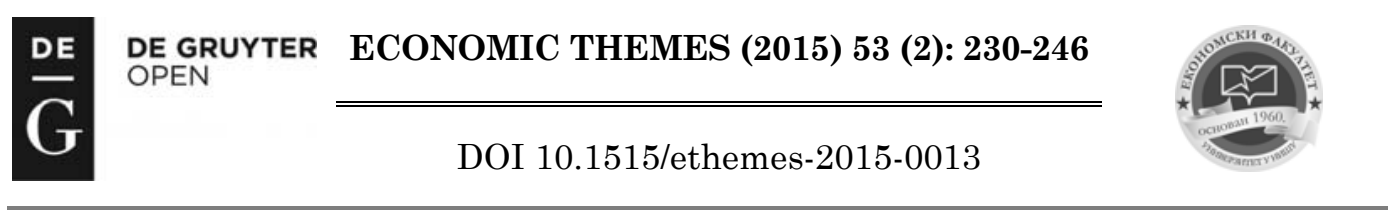

\title{
ANALYSIS OF CULTURAL RESOURCES OF SOUTHEAST EUROPEAN COUNTRIES AS A FACTOR OF TOURISM COMPETITIVENESS
}

\author{
Sonja Jovanović \\ University of Niš, Faculty of Economics, Serbia \\ $\bowtie$ sonja.jovanovic@eknfak.ni.ac.rs \\ Snežana Đekić \\ University of Niš, Faculty of Economics, Serbia \\ $\triangle$ snezana.djekic@eknfak.ni.ac.rs \\ Ivana Ilić \\ PhD student, University of Niš, Faculty of Economics, Serbia \\ $\bowtie$ ivanica1404@yahoo.com
}

UDC

338.483 .12

(4-12)

Original

scientific

paper

Received:

20.11.2014

Accepted:

27.03.2015

\begin{abstract}
The former role of tourism in terms of provision of accommodation and food has become outdated. Tourist offer increasingly includes additional activities, such as visits to various tangible and intangible cultural sites, and events that tourists perceive visually. In the contemporary tourism trends, cultural resources of Southeast European countries have become an important factor that maintains the competitiveness under conditions of the growing competition on a world scale. Cultural resources directly affect tourism, but there is also an inverse relationship reflected in the impact of tourism on cultural resources that are becoming an important factor for the choice of tourist destinations. The subject of this paper is to review the contribution of cultural resources to the development of tourist destinations with the help of the analysis of elements of Travel and Tourism Competitiveness Index - TTCI.
\end{abstract}

Keywords: cultural resources, competitiveness, tourism, TTCI, the Southeast European countries.

This paper is realized within projects No. 179066 and 031020 financed by Ministry of Education and Science, Republic of Serbia. 


\section{Introduction}

Tourism is seen as a specific activity that has a direct impact on sustainable economic and social development, given the importance of its contribution to the gross domestic product. It is recognised as one of the key sectors of development in many countries, a significant source of income, jobs and a successful way to generate wealth. Furthermore, it has a role in promoting a country, and thus stands for a significant factor of domestic policies. Due to the complexity of all roles that the tourism sector has, there are challenges in expressing its competitiveness. In recent years, competitiveness is one of the most common concepts that determine the sustainable development of travel and tourism sector. Determining the competitiveness of the tourism sector of a country is an important factor for policy makers in making concrete decisions. Managing competitiveness of tourist destinations in contemporary business conditions is one of the most important segments of the tourism development policy. For the purpose of measuring the competitiveness of travel and tourism sector, the methodology of Travel and Tourism Competitiveness Index - TTCI has been developed by the World Economic Forum. This index allows for the analysis of the factors and policies that make a country a viable place for investment in the sector of travel and tourism. Specifically, the index provides a detailed insight into the competitiveness of the travel and tourism sector through the analysis of impact factors included in its structure. It also points out the key areas that need to be improved for the purpose of increasing the competitiveness of this sector in relation to other countries, and thus achieving the economic development of the country under consideration. The subject of analysis in this paper is to investigate the impact of cultural resources on the competitiveness of travel and tourism sector. The aim of the paper is to highlight the degree of impact of the components of cultural resources on the total value of the pillar cultural resources.

\section{Review of Literature}

The travel and tourism sector has been identified as a key sector and a catalyst of economic growth and development in many countries in the world. In countries characterised by lower level of development, the tourism sector is considered important in conducting the policy of poverty reduction. Tourism has the potential to generate foreign currency revenues and increase employment in a competitive destination. This can help to diversify economic activity, which allows countries to redistribute wealth and jobs from developed to less developed areas (WEF, 2007). In this way, tourism plays the role of balancing regional development. Consequently, the development trend in both underdeveloped and developed countries is to treat tourism as an economic and social phenomenon and potentially profitable investment area (Berberoglu 
1988). Countries that operate on the international tourism market are constantly forced to seek the best way to provide customer satisfaction, thus increasing competition (Turanli, Guneren 2003). In other words, the competition between the popular tourist countries causes an ongoing struggle for the improvement and establishment of competitive advantage (Cimat, Bahar 2003). The competitiveness of tourist destinations, and generally, the overall competitiveness of the travel and tourism sector, has become highly important for the survival of the tourist destination on the international market, under conditions of increasing leisure time and rising levels of disposable income (Echtner, Ritchie 2003). According to the UNWTO (World Tourism Organization), in 1950, the top fifteen tourist destinations attracted almost all tourists from the total number of tourists in the world (98\%), and after sixty years, that percentage has decreased to $57 \%$ (UNWTO, 2008). The focus of tourism organisations today, instead of simply attracting as many tourists, is shifted to the creation of competitive tourist destinations.

The competitiveness of tourist destinations is a complex and relative concept, and part of this complexity arises from the definition of a tourist destination. As each destination has different tradition, history, cultural and natural resources, as well unique ambitions and the means for achieving the objectives, different models for measuring the competitiveness of tourist destinations have been created. The most commonly used are the integrated and conceptual model by Ritchie and Crouch (Ritchie, Crouch 2003) and the model developed by the World Economic Forum for the needs of the Travel and Tourism Competitiveness Index.

The competitiveness of tourism is affected by a broad set of factors or determinants. The literature on tourism recognises tourism competitiveness as a relative, multidimensional, and complex concept, defined by a series of economic, political, environmental, and cultural variables (Craigwell, 2007).

The World Economic Forum is actively engaged in the study of national competitiveness, in order to better understand and identify the drivers of growth and development. By developing the TTCI, it created benchmarking tool, which allows countries to identify key obstacles to improving competitiveness and achieving the level of competitiveness of the best destinations or countries. Under such circumstances, the platform for the dialogue between government, business, and civil sectors is provided, so that their joint activities could eliminate the weaknesses identified. In that context, the main objective of the Travel and Tourism Competitiveness Index is to investigate the driving factors of competitiveness of travel and tourism sector. This provides the basis for defining and implementing development policies at the state level. There is a difference in the definition of the driving factors of the development of tourism, depending on the development of a country. Although some of the factors are "must have" for economies with high income, they may not be essential for the 
developing countries. The importance of certain factors that make the TTCI varies, depending on the stage of development of each country. Political stability, for example, is a prerequisite for any country that seeks to attract tourists (Dwyer, Kim 2003). The World Travel and Tourism Council (WTTC) suggests that the TTCI can be used to determine the directions and strategies that countries at different stages of economic development could use to make the travel and tourism sector more competitive. One important assumption is that governments create an environment that creates opportunities for the development of the travel and tourism sector. The analysis of the TTCI may be important in clarifying strengths, weaknesses, opportunities, and threats of a country in the process of further development of tourism.

Furthermore, WTTC notes that for the successful development of the travel and tourism sector, the development of the entire economy of a country is important. Thus, economically strong countries should, in order to improve their travel and tourism sector, seek to fully exploit their existing resources, with special focus on the preservation of monuments, tourist sites, and areas of natural beauty. In contrast to these countries, low-income economies should consider possible benefits in terms of income and new jobs in the process of development of travel and tourism sector.

For the purposes of measuring the achieved level of competitiveness of the travel and tourism sector at the international level, in 2007 the World Economic Forum defined the Travel and Tourism Competitiveness Index. The structure of this index consists of three sub-indices, namely: 1) regulatory framework, which includes elements related to state policies; 2) subindex which examines the business environment and infrastructure, which evaluates the overall business environment and economic infrastructure of the country; 3) subindex related to human, cultural and natural resources of each country. Within the subindex human, cultural, and natural resources, a significant pillar refers to cultural resources, as one of the critical drivers of competitiveness of the travel and tourism sector worldwide. Cultural resources are the collective evidence of people's previous activities and achievements (New York Archaeological Council Standards Committee, 2000). According to the Law on Cultural Property of the Republic of Serbia (Official Gazette of RS, 71/94), all the achievements of man, whether of material or spiritual nature, are united under the notion of cultural property. Under this law, cultural property refers to objects and creations of material and spiritual culture that have such properties that meet some or all cultural needs of a modern man. As such, they are an essential part of tourist movements, or part of socio-cultural and spatial phenomena. "Cultural heritage includes considerations of built heritage (historic and architectural), archaeological heritage and socio-cultural heritage." (Cooper et al. 2008) The cultural resources are an important element of the tourist product and the key carrier of attractiveness of a destination. It is expected that 
"population are becoming more culturally diverse as improved communications, increasing wealth and mobility stimulate people to try to understand other culture" (Cooper et al. 2008).

Destinations that are able to offer tourists access to a unique experience through the local culture achieve competitive advantage and the basis for generating publicity among tourists. According to Mieczkowski (1995) cultural tourism is a part of alternative forms of tourism such as educational, scientific, adventure and agritourism.

Competitive advantage achieved by using the cultural resources of a destination leads to long-term sustainable growth and development of tourism, through the valorisation of cultural heritage and environmental protection. "Tourism should bring benefits to host communities and provide an important means and motivation for them to care for and maintain their heritage and cultural practices." (ICOMOS 1999) The cooperation of all stakeholders (local community, tourism operators, policy makers, conservationists) can bring to achieving sustainable cultural tourism.

The concept of sustainable cultural tourism has several principles and presents a very complex process which needs careful consideration. This process has several steps where "each step has a counterpart in the principles and guidelines and is important in ensuring that the objectives are realised on the ground". (Richards 2005, p. 8) Process and principles of sustainable cultural tourism presented in Figure 1.

Figure 1 Sustainable Cultural Tourism and the Visitor Journey

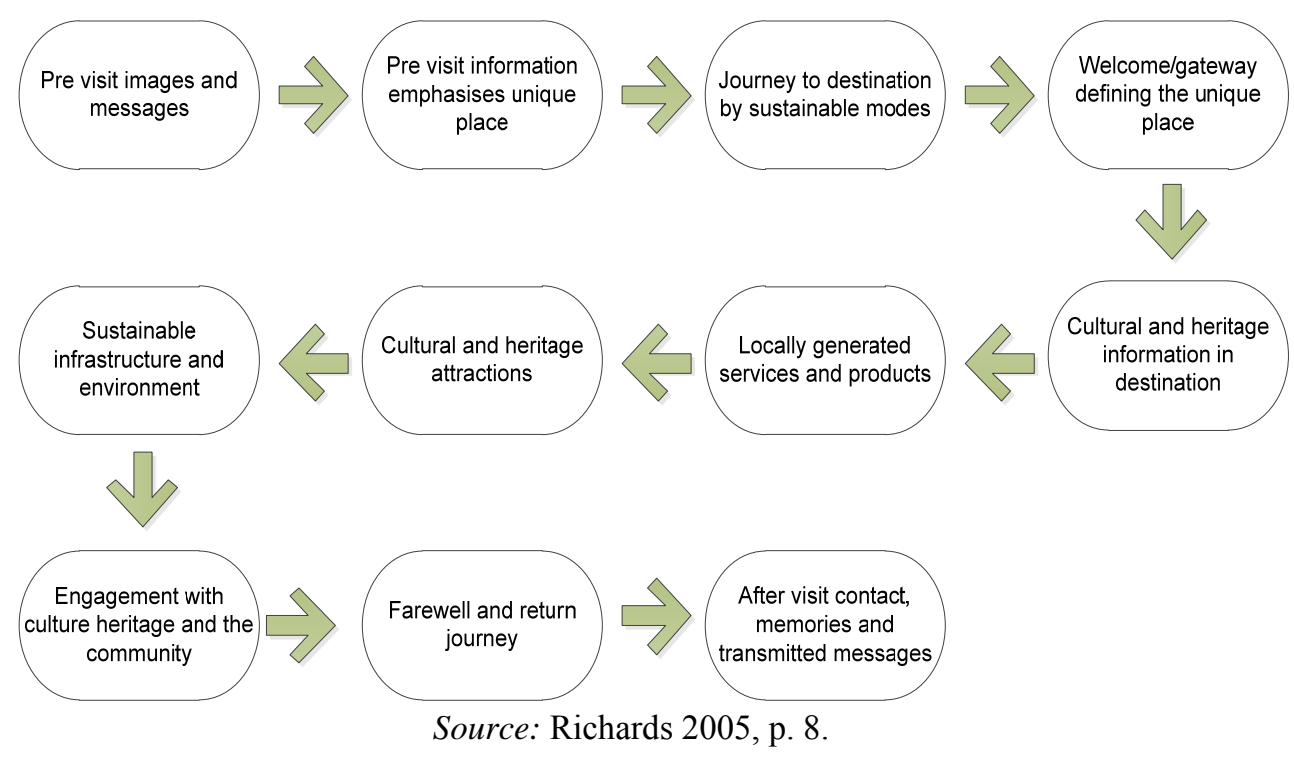


It is necessary to devise a path from genuine cultural resources which are abundant in some destinations to the end tourist product which will make this destination different from all others and suitable for the development of cultural tourism. Cultural tourism is the integration of tourism with culture, and contributes to the conservation of cultural property. "The interest in local culture, arts and crafts, historic places, and the like, as aroused by tourists, can lead to regeneration in awareness, interest and pride in local culture" (Collier 2007, p. 366). The main objective of cultural tourism is to encourage and motivate tourists to travel and become familiar with local cultural values. It should be noted that cultural tourism is not just passive watching and exploring, but also active participation, reflection, and experience obtained in the sociocultural processes.

The pillar of the Travel and Tourism Competitiveness Index, cultural resources, includes the following components in its structure: the number of UNESCO world heritage cultural sites, the capacity of sports stadiums, the number of international fairs and exhibitions at home, and "creative" industry exports. The number of UNESCO world heritage cultural sites within a destination is of great importance for increasing the competitive advantage of that destination, and attracting a large number of tourists from around the world. Cultural heritage (monuments, monumental entities, and monumental areas), which are on the UNESCO World Heritage list, certainly possesses outstanding universal value. The aim is to protect cultural property along with the extension of its life and the preservation of its quality and value. Thus, by applying the principles of sustainable development, tourism can be a tool to achieve benefit and higher living standard for local people, based on the preservation and promotion of sites for future generations. Capacity of sports stadiums is essential for the development of sports tourism that involves travelling and where the primary motivation is active or passive engaging in sports and sports activities. Sport contributes to the development of tourism in certain destinations where important sports events that attract large numbers of tourists are held, in terms of economic performance, enrichment of offer, and strengthening of tourist image. Capacity of sports stadiums is important for diversification of the tourist offer, as it increases attractiveness of this destination. International fairs and exhibitions are seen as important for the tourist offer of the destination. Their organisation at a particular destination provides stimulus to economic, art, educational, and other important activities of social life. In addition to complementing the tourist offer, fairs and exhibitions promote tourism in a particular tourist destination and have direct social and cultural implications for their participants. The last but not least important component of the TTCI pillar - cultural resources is "creative industries" exports. This covers the export of films, photographs, jewelery, music, books. Seen from this perspective, the export of products of "creative" industry promotes a particular country by displaying its natural beauty, 
tradition, culture, and arts. In this way, it is possible to attract a greater number of international tourists and make a destination more competitive in comparison to others (Jovičić, Mikić 2006).

"There is no doubt that culture is an important tourism resource in Europe, and that maintaining the competitiveness of the European tourism product is vital" (Richards 2005, p. 10). An increasing number of destinations in Europe based its development on cultural resources in the race for the preservation of a dominant position in the international tourism and cultural market. The challenge in the future to be reached is growing competition in the sphere of cultural tourism industry.

\section{Methodology}

The subject of analysis in this paper is to investigate how cultural resources, as the pillar of the Travel and Tourism Competitiveness Index, affect the competitiveness of the tourist sector. A comparative analysis of the values of this pillar in several countries of Southeast Europe is carried out (Serbia, Macedonia, Bulgaria, Albania, Bosnia and Herzegovina, Croatia, Slovenia, and Hungary). In other words, this paper analyses the correlation between individual elements of the TTCI and the total TTCI.

Bearing in mind the structure of the TTCI, the aim of this paper is to determine the degree of impact of the value of the individual components comprising the pillar - cultural resources on its total value, as well as how the value of the pillar - cultural resources affects the value of the subindex human, cultural, and natural resources and the total value of the TTCI. This means that the impact of cultural resources on competitiveness needs to be explored, as well as which components of this pillar need to be improved in order to increase the total tourism competitiveness.

In this paper, methods of statistical analysis are used. Special emphasis is on the application of correlation and regression analysis. With the help of these methods, it is possible to determine the nature of the correlation, the significance of correlation, and the impact of individual parameters on the TTCI.

Information base consists of research data provided by the World Economic Forum, the World Tourism Organisation, the International Union for Conservation of Nature, and the World Travel and Tourism Council. For the purposes of methodological explanations and analysis, data from the Travel and Tourism Competitiveness Report of the World Economic Forum for the period from 2007 to 2013 are used.

The research in this paper consists of three parts: I) The first section involves the analysis of the values of the TTCI for the countries included in the analysis; II) The second part discusses the value of the subindex of the TTCI - 
human, cultural, and natural resources. More detailed research is dedicated to the values of the pillar - cultural resources and its components, for each of the analysed countries; III) Using the methods of statistical analysis, a correlation between the pillar - cultural resources and the total TTCI is determined with respect to the considered countries. Regression analysis examines the degree of impact of the pillar on the Travel and Tourism Competitiveness Index and the impact of the components of the pillar - cultural resources on its total value. This section also focuses on the cluster analysis, meaning that specific countries are classified into homogeneous groups, according to the level of competitiveness of their cultural resources.

\section{Research Results and Discussion}

\section{I) Examining the Competitiveness of Southeast European Countries, Based on the TTCI Value}

The study relies on the data obtained from the Travel and Tourism Competitiveness Report for 2007, 2008, 2009, 2011, and 2013, including all available reports regarding this Index. In different years, the coverage of countries is different. Thus, in 2007, the Report included 124 countries, in 2008 130 countries, in 2009133 countries, in 2011139 countries, and in 2013140 countries worldwide. In the 2007 Report, Serbia and Montenegro is seen as one country, which is particularly emphasised and discussed in further analysis in this paper. By applying a comparative analysis of the value or ranking, each country is compared with other countries in the group and observed with respect to the analysed period. The achieved level of tourism competitiveness of the countries of Southeast Europe based on the TTCI for the period 2007-2013 is shown in Graph 1.

According to the TTCI for 2007, within the observed group of countries, Croatia, Hungary, and Slovenia are highly ranked, having approximate values of the TTCI. These are also the countries that are highly ranked within 124 countries considered in the Travel and Tourism Competitiveness Report Index for the above-mentioned year. On the basis of this Report, Bulgaria occupies the $54^{\text {th }}$ place, whereas Serbia and Montenegro occupy the $61^{\text {st }}$ position. The countries that are worse than Serbia and Montenegro are Macedonia $\left(83^{\text {rd }}\right)$, Albania $\left(90^{\text {th }}\right)$, and Bosnia and Herzegovina $\left(104^{\text {th }}\right)$. The positioning of countries in the following year, 2008, is similar to the previous year, except that the TTCI values are slightly lower than in 2007 . The TTCI values in the group of analysed countries in this year range from 4.59 to 3.45. The declining trend in the TTCI value is also characteristic for 2009, except for Macedonia, Albania, and Montenegro, whose TTCI value increased, and whose ranking improved. In 2011, the declining trend in the TTCI value was interrupted, and then all countries recorded growth in the TTCI value. The best ranked country 
in the observed group of countries in the indicated year was Slovenia $\left(33^{\text {rd }}\right)$, while Bosnia and Herzegovina had the lowest position $\left(97^{\text {th }}\right)$. Based on the Report from this year, Serbia improved the value of the TTCI, as well as the position in the list of ranked world countries.

Graph 1 The Achieved Level of Competitiveness in Tourism of Southeast European countries based on the TTCI for the period 2007-2013

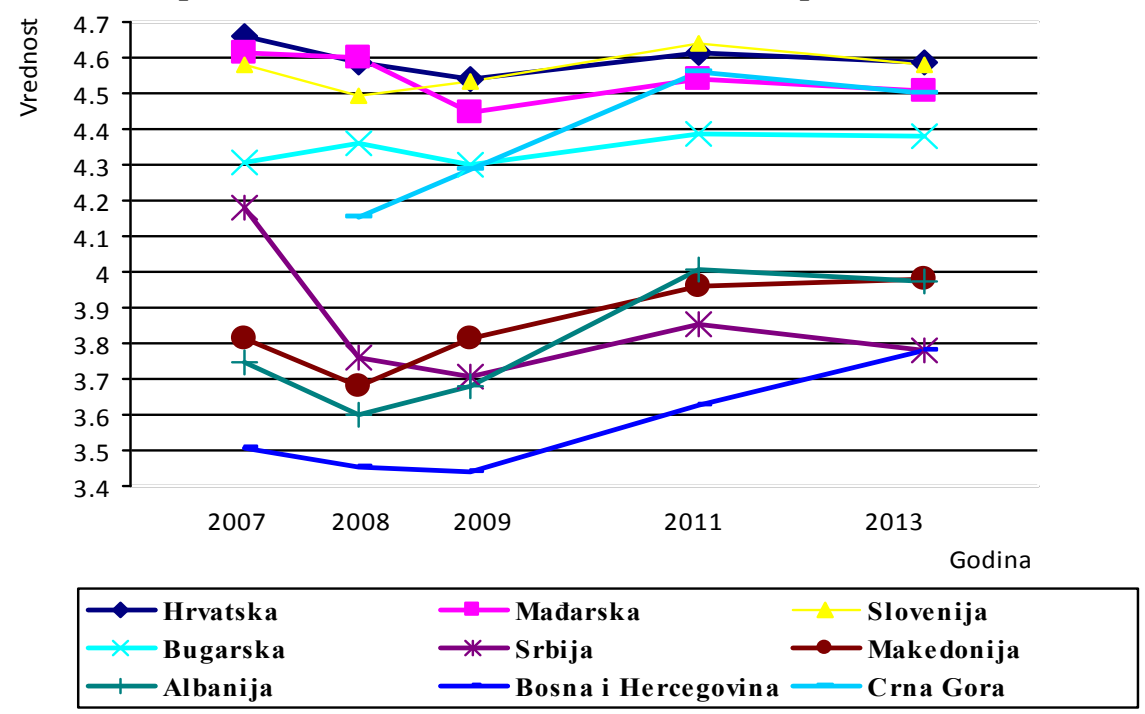

Source: The Travel and Tourism Competitiveness Report for 2007, 2008, 2009, 2011, and 2013, World Economic Forum, Geneva, Switzerland

The last analysed year (2013) did not bring significant changes in the TTCI values of the countries included in the research in this paper. With respect to this year, Bosnia and Herzegovina made the largest shift in the rankings in relation to the previously analysed year. ${ }^{2}$ Over the years, the TTCI value of Albania and Macedonia increased, while in Serbia it decreased greatly, which is seen in the fact that in 2007 it was 4.18, and 3.78 in 2013, which led to the fall from the $61^{\text {st }}$ place to the $89^{\text {th }}$ place in 2013 .

\section{II) Analysis of Subindex - Human, Cultural, and Natural Resources in Southeast European countries}

The aggregate indicator (the TTCI value) does not always have a great analytical value, so that deeper analysis of the subindex - human, cultural, and natural resources will be carried out. Top ranked countries in 2007, according to the value of the subindex, were Croatia and Serbia, which occupied the

\footnotetext{
${ }^{2}$ In all reports for the analysed years, the highest TTCI value and the first position in the world were held by Switzerland, whereas the lowest value and the lowest ranking were held by Chad.
} 
eleventh and thirteenth position, respectively. Other countries were far lower on the list of all countries, so that Bosnia and Herzegovina occupied $108^{\text {th }}$ position, which is the worst position in the group of analysed countries. During 2008 and 2009 , the value of the subindex in the observed group of countries declined, leading to the shift of countries to lower positions on the list. A slight increase in the value occurred in 2011, when the subindex value ranged from 4.38 (Montenegro) to 3.60 (Serbia). The 2013 Report shows similar values of the subindex - human, cultural, and natural resources as in 2011, whereby all the analysed countries had the ranking lower than 42. In Serbia, in the period from 2007 to 2013, the value of the observed subindex and the ranking significantly worsened, as it moved from the $13^{\text {th }}$ position to the $109^{\text {th }}$ position in the rankings.

The structure of the pillar - cultural resources was different in 2007 compared to other years, as the analysis combined natural and cultural resources. In that period, this pillar consisted of the following components: number of UNESCO world heritage cultural sites, carbon dioxide damage (CO2), nationally protected areas, business concern for ecosystems, and the risk of malaria and yellow fever (World Economic Forum, 2007). In the 2007 Report, countries are ranked from the $26^{\text {th }}$ (Serbia) to the $100^{\text {th }}$ position, occupied by Bosnia and Herzegovina. The pillar values were much lower in 2008 , when natural and cultural resources were separately observed. In most of the analysed countries, one could note halved values of the said pillar in 2008, compared to 2007. In this year, Hungary had the best position on the list $\left(23^{\text {rd }}\right)$, whereas Albania occupied the lowest, $75^{\text {th }}$ position. The fall in the value of the pillar was also characteristic for 2009, when Bulgaria had the largest decline. In 2011, Hungary and Croatia were in the group of high-ranked countries. In the same year, Albania had the lowest value and occupied the $83^{\text {rd }}$ position in the rankings, whereas Macedonia and Bosnia and Herzegovina were slightly ahead of it. When Hungary and Croatia are taken into consideration, the situation remained unchanged in 2013. The group of lower ranked countries from the group of analysed countries includes Albania, Macedonia, Bosnia and Herzegovina, and Serbia. With respect to the period analysed in this study, it can be seen that the value of the pillar and the position of Serbia in the rankings based on that value considerably decreased, except for 2011, when the value of the pillar improved slightly. However, the decline continued in 2013.

Within the pillar - cultural resources, its constituent components are considered, whose values form the total value of the pillar. Data on these components is characterised as "heavy/hard" data, obtained from international organisations or national sources. Furthermore, there is a data discrepancy regarding the year from which it was taken and the year for which the value of the component is calculated. The number of UNESCO World Heritage cultural sites is a component of the pillar - cultural resources which was observed over all years. The greatest number of UNESCO world heritage cultural sites is 
found in Croatia and their number increased over time. According to the number, it is followed by Hungary and Bulgaria, both of which, according to the last report, have nine UNESCO world heritage cultural sites. Bosnia and Herzegovina, Slovenia, and Albania have two or three UNESCO sites. Macedonia and Montenegro are characterised primarily by one UNESCO world heritage cultural site. Serbia has four UNESCO World Heritage cultural sites. The most significant sites are: Stari Ras with Sopoćani (the entity which includes Monastery Sopoćani and Đurđevi Stupovi, Peter's Church, and the remains of Ras and Gradina), Monastery Studenica, Gamzigrad and medieval monuments in Kosovo (Monastery Dečani, the Patriarchate of Peć, Gračanica, and the church Our Lady of Ljeviš) (Tourist Organisation of Serbia). The next component that was calculated only for 2007 is the carbon dioxide damage. The value of this component for the observed countries ranged from 0.2 to 1.6. The lowest value, and therefore a high position in the rankings, was held by Albania $\left(27^{\text {th }}\right)$. Bosnia and Herzegovina was among the lowest-ranked countries $\left(109^{\text {th }}\right)$. In the Reports that followed the 2007 Report, sports stadiums were observed, in terms of their capacity per one million inhabitants. Based on this component, the countries from the analysed group were highly-rated over the whole period of analysis. Montenegro is, according to the latest Report, in the fourth place, and represents the leading country of Southeast Europe on the basis of the capacity of sports stadiums. For a five-year period (2008-2013), the capacity of sports stadiums in Serbia did not significantly change, which affected the maintenance of approximately the same position in the rankings over time. Nationally protected areas, as a component of the pillar - cultural resources, shows the percentage of nationally protected areas on the entire territory in 2007. According to the evaluation of the World Economic Forum, based on the available data, there is $7.5 \%$ of the nationally protected areas in Croatia, which is the highest percentage among the analysed countries. For Serbia, there was no information, and the smallest percentage was recorded in the case of Bosnia and Herzegovina. Since 2008, a new component in the analysis of this pillar of competitiveness has been introduced - the number of international fairs and exhibitions held every year in a country. The value of this component increased over time for all countries, except Macedonia. The country with the highest number of international fairs and exhibitions was Hungary, according to the latest Travel and Tourism Competitiveness Report. In Serbia, this number significantly increased, so that this country moved from the $64^{\text {th }}$ position in 2008 to the $48^{\text {th }}$ position in 2013, having 45.7 international fairs and exhibitions for the year. When business concern for ecosystems is taken into consideration, in terms of taking action for their preservation, Slovenia was the best ranked country in the group, followed by Hungary. Group of countries that express irregular concern for ecosystems and thereby influence their degradation includes Albania and Serbia. Since 2009, the pillar - cultural resources has included another component, creative industries exports, which is presented as a 
country's share in the total world exports of these products. Over the years, all countries of Southeast Europe recorded low share, ranging from $0 \%$ to $0.3 \%$. Hungary had the highest percentage of creative industries exports, $0.3 \%$. Countries that do not have a share in creative industries exports are Serbia, Macedonia, Albania, Bosnia and Herzegovina, and Montenegro. The risk of malaria and yellow fever in 2007 did not exist in the analysed countries, placing them all on the first position in the world rankings.

\section{III) Examination of the Correlation Between the Pillar - Cultural Resources and the Travel and Tourism Competitiveness Index in Southeast European countries}

Using the statistical method, the correlation analysis, the correlation between the pillar - cultural resources and the Travel and Tourism Competitiveness Index was investigated, as well as the character and strength of the correlation. By calculating the Pearson coefficient of correlation for the two abovementioned variables in a given time period, it can be seen that among them there is a medium strong to strong and positive correlation, while the correlation coefficient is statistically significant for each year observed. The highest degree of quantitative agreement between the variables occurred in 2009, when Pearson's coefficient had a value of 0.808 , indicating a high level of compliance of the pillar - cultural resources and the values of the total TTCI. In addition, in this year, the level of significance (P-value) had the lowest value, 0.008, indicating that the correlation between the observed variables was highly significant. Spearman correlation coefficient shows the approximate values to the Pearson correlation coefficient, where the values of the coefficient are ranked. The highest compliance of rankings was observed in 2008, while the lowest was in 2007. In this way, it was found that increasing the value of the pillar - cultural resources can have an impact on the increase in the value of the Travel and Tourism Competitiveness Index, but its total value depends on the movement of the other parameters (pillars).

Table 1 Values of Pearson's and Spearman's Correlation Coefficients Between the TTCI and the Pillar - Cultural Resources for the Group of Observed Countries over the Period 2007-2013

\begin{tabular}{|c|c|c|c|c|}
\cline { 2 - 5 } \multicolumn{1}{c|}{} & $\begin{array}{c}\text { Pearson } \\
\text { Correlation } \\
\text { Coefficients }\end{array}$ & P value & $\begin{array}{c}\text { Spearman } \\
\text { Correlation } \\
\text { Coefficients }\end{array}$ & P value \\
\hline 2007. & 0,758 & 0,018 & 0,563 & 0,114 \\
\hline 2008. & 0,713 & 0,031 & 0,833 & 0,005 \\
\hline 2009. & 0,808 & 0,008 & 0,800 & 0,010 \\
\hline 2011. & 0,759 & 0,018 & 0,633 & 0,067 \\
\hline 2013. & 0,759 & 0,018 & 0,787 & 0,012 \\
\hline
\end{tabular}

Source: Authors' calculation 
After the application of the correlation analysis, the regression analysis was applied to the same variables. The regression analysis determined the correlation between the two variables, the pillar - cultural resources, which stands for the independent variable, and the TTCI, which represents the dependent variable. Based on the regression model, it can be seen to what extent a unit increase in the value of the pillar - cultural resources affects the change in the value of the Travel and Tourism Competitiveness Index. For the first year observed, increase in the value of the pillar - natural and cultural resources by one value unit causes an increase in the value of the TTCI by 0.45 on average. For the following years of the analysed period, except for 2009, it is characteristic that a unit increase in the value of the pillar - cultural resources affects the change of the TTCI value by approximately 0.3 . In 2009, the TTCI increased by 0.53 on average when the value of the pillar - cultural resources increased by one unit. Over the years, the determination coefficient was greater than 0.5 and, consequently, the model was statistically representative and could be used to predict the general trend of the TTCI value depending on the pillar cultural resources. Therefore, it was found that it is possible to predict the value of the dependent variable relative to the assumed value of the independent variable, and the effect of changes of the independent variable in relation to the dependent variable.

Multiple regression analysis examined the impact of the values of the pillar components on its total value. During all the years analysed in this paper, the value of the coefficient of determination indicated that the model was statistically representative. Multiple regression model in 2007 was different compared to other years, because the components of the pillar - natural and cultural resources are observed. The growth of the components - the number of UNESCO World Heritage cultural sites and business concern for ecosystems by one value unit affected the increase in the value of the pillar by 0.105 on average, or 0.243 , while the component - carbon dioxide damage caused a reduction in the value of the pillar by 0.856 . The risk of malaria and yellow fever should be as low as possible, and change in the value of this component by one value unit significantly increased the pillar value (0.975). Nationally protected areas are expressed in percentage, and their value increased by $1 \%$ led to a slight increase in the value of the pillar. To calculate the value of the pillar - cultural resources in 2008, the components number of UNESCO World Heritage cultural sites, sports stadiums, and the number of international fairs and exhibitions were used. A unit increase in the value of the number of UNESCO World Heritage cultural sites and the number of international fairs and exhibitions increased the value of the pillar by 0.19 , or 0.014 . When increased by one index point, the component - sports stadiums influenced the increase of the pillar by 0.12 . In all subsequent years analysed, in addition to the previously mentioned components, the component - creative industries exports was taken into account. If the impact of the component - the number of 
UNESCO world heritage cultural sites on the value of the pillar in 2009, 2011, and 2013 is taken into account, it is observed that its unit increase caused all the small increase in the value of the pillar $(0.120$ to 0.082$)$. The case was the same with the component number of international fairs and exhibitions, whose rise by one unit caused an extremely low increase in the pillar values over the years. Sports stadiums, as a component of the pillar cultural resources, with an increase of one index point, caused an increase in the value of the pillar by approximately 0.1 in all the rest of the analysed years. The increase in creative industries exports from 2009 to 2013 by $1 \%$, significantly affected the increase in the value of the pillar cultural resources. According to the results obtained by multiple regression, during the selected time interval, the components with the highest impact on the value of the pillar were sports stadiums and creative industries exports. To enhance the value of the pillar cultural resources, and thus improve a position in the world rankings in terms of travel and tourism competitiveness, Serbia should increase the capacity of sports stadiums and start exporting products of "creative" industries.

Cluster analysis examined the interdependence of several variables, with the purpose of their classification into groups based on their similarity regarding the series of observed characteristics. The components of the pillar - cultural resources were grouped into three clusters, for each year separately. In 2007, most of the analysed countries were in the first cluster, which grouped the countries that give the greatest importance among the observed components to the risk of malaria and yellow fever. Only one country was placed in the second cluster, which highlighted the component the number of UNESCO World Heritage cultural sites. The third cluster included two countries (Bosnia and Herzegovina and Albania). The structure of the pillar - natural and cultural resources in 2007 consisted of different components in relation to the following years, so the resulting data of cluster analysis were diametrically different in relation to the following year. For 2008, it was characteristic that out of the nine analysed countries, only one country (Hungary) in the second cluster attached importance to the number of UNESCO World Heritage cultural sites and the number of international fairs and exhibitions. The first cluster classified six countries, where the capacity of sports stadiums, as a component of the pillar cultural resources, was pronounced. The other two countries (Croatia and Slovenia) belong to the third cluster. As in the previous year, Hungary was in 2009 in the second cluster, which had unchanged characteristics. Furthermore, Croatia and Slovenia were in the third cluster, in which the component the capacity of sports stadiums was influential, while all other countries were in the first cluster. An identical situation occurred in 2011, when there were no changes in the composition of any of the clusters. Cluster analysis for 2013 shows that most of the analysed countries were located in the third cluster, which included countries with the maximum value of the component capacity of sports stadiums. Hungary was, as well as in all previous years, in the second 
cluster, whereas the first cluster included the three countries (Croatia, Slovenia, and Serbia). It is noted that during all these years Hungary was the leading country by number of UNESCO World Heritage cultural sites and the number of international fairs and exhibitions, which put it into a separate cluster. Other countries changed the cluster to which they belonged, depending on the estimated competitiveness of the components.

\section{Conclusion}

The tourism sector, under modern living conditions, has a significant contribution to economic development in many countries. Its contribution is significant for economic development, but there is always the potential for advancement and improvement. Tourism is expected to be interdisciplinary, combining various factors that affect growth. For the success of tourism, it is necessary to develop attractive tourist destinations that are more competitive and able to attract large numbers of tourists. In order for the tourism development policy makers to be able to direct further development of the tourism sector through strategic activities, it is essential to conduct benchmarking analysis or comparison with the achieved level of development of this sector in other countries. Therefore, the knowledge of the achieved level of competitiveness of the tourism sector, as well as the analysis of the factors that determine the competitiveness, is of utmost importance. For the purpose of measuring the competitiveness of a destination, the World Economic Forum developed the Travel and Tourism Competitiveness Index. Based on the analysis of the TTCI, countries are able to assess their performance relative to other countries of the world, and identify their own weaknesses and opportunities for improving development.

Human, cultural, and natural resources are the subindex within the Travel and Tourism Competitiveness Index, on which the overall competitiveness of the tourism sector of each country largely depends. Cultural resources are the pillar within this subindex, which has been the subject of particular interest in this work. By placing emphasis on cultural resources, many countries realise the benefits of tourism. In Serbia, cultural tourism has not yet found a place in purposeful research or in designing strategic development plans, although there are cultural resources of international importance. To improve the competitiveness of tourist destinations in Serbia in terms of cultural resources, as the pillar of the TTCI, the conclusion arising from this research points to the need for the organisation of a large number of international fairs and exhibitions, sports events, and encouragement of "creative" industries so that its products could have a high share in the total world exports of products of this industry.

Group of observed countries of Southeastern Europe, after the cluster analysis, it is fairly homogeneous according to the characteristics of cultural 
tourism. The only are separated Croatia and Slovenia that make a special cluster and Hungary, which is different from other countries, according to the number of UNESCO World Heritage cultural sites and number of international fairs and exhibitions. Serbia, Macedonia, Bulgaria, Albania and Bosnia and Herzegovina are fairly homogeneous according to the basic components of pillar - cultural resources. Regardless of significant potential in terms of cultural resources there is need of significant and continuous improvement of each of the components in order to achieve a higher level of attractiveness and competitiveness.

\section{References}

Berberoglu, N. C. (1988) Economic Development Tourism, Eskisehir Anadolu University Faculty of Economics and Administrative Sciences Journal 2: 207-218.

Cimat, A., Bahar, O. (2003) Arrange the location and importance of the tourism sector in Turkey in Evaluation Economics, Faculty of Economics Mediterranean Magazine,6: 1-18.

Collier, A. (2007) Principles of Tourism, Pearson Education New Zeland.

Cooper, C., Flecher, J., Fyall, A., Gilbert, D., Wanhill, S. (2008) Tourism - Principles and Practice, England: FT Prenctice Hall - Financial Time.

Craigwell, R. (2007) Tourism competitiveness in small island developing state. United Nations University, UNU-WIDER 2007.

Dwyer L., Kim C.W. (2003) Destination Competitiveness: a Model and Indicators. Current Issues in Tourism, 6 (5): 369-413.

Dwyer, L., Forsyth, P., Dwyer, W. (2011) The travel and tourism competitiveness index as a tool for economic development and poverty reduction. In L. Moutinho (ed.), Strategic Management in Tourism, $2^{\text {nd }}$ ed. Wallingford, UK: CAB International, pp. 33-52.

Echtner, C.M., Ritchie, J.R.B. (2003) The meaning and Measurement of Destination Image. The Journal of Tourism Studies, 14(1): 37-48.

Grunewald, R., A. (2002) Tourism and cultural revival. Annals of Tourism Research, 29 (4): 1004-1021.

Jovičić, S., Mikić, H. (2006) Creative industries - Basic facts and policy recommendations for Serbia, British Council Belgrade.

ICOMOS (International Council on Monuments and Sites) (1999) International cultural tourism chapter - Managing Tourism at Places of Heritage Significance, Mexico.

Law on cultural properties of the Republic of Serbia, Official Gazette of RS, No. 71/94.

Mieczkowski Z. (1995), Environmental issues of tourism and recreation, University press of America, Maryland.

Moutinho, L. (2011) Strategic Management in Tourism. CABI

National Tourism Organisation of Serbia, http://www.srbija.travel/kultura/unescoliste/svetska-kulturna-bastina/ (4.2.2014.)

New York Archaeological Council standards committee (NYAC), (2000) Guidance for understanding and applying the New York state standards for cultural resource investigations. 
Ritchards, G. (2005) Cultural tourism in Europe, CABI, Wallingford.

Ritchie, J.R.B., Crouch, G.I. (2003) The competitive destination: A sustainable tourism perspective, CABI Publishing.

The Economist, http://www.economist.com/ (8.2.2014.)

The Organisation for Economic Cooperation and Development (OECD), http://www.oecd.org/cfe/tourism/Indicators\%20for\%20Measuring\%20Competitive ness\%20in\%20Tourism.pdf (1.2.2014.)

The World Travel \& Tourism Council, www.wttc.org (1.2.2014.)

Tourist Organization of Serbia, World Cultural Heritage, http://www.srbija.travel /kultura/unesco-liste/svetska-kulturna-bastina/ (25.05.2014)

Turanli, M., Guneren, E. (2003) Tourism Sector in Demand Forecasting Modeling, Istanbul Commerce University Magazine, 6: 1-13.

United Nations Educational, Scientific and Cultural Organization (UNESCO), http://whc.unesco.org/ (10.2.2014.)

World Economic Forum (2007) The Travel and Tourism Competitiveness Report 2007: Furthering the Process of Economic Development, Geneva.

World Economic Forum (2008) The Travel and Tourism Competitiveness Report 2008: Balancing Economic Development and Environmental Sustainability, Geneva.

World Economic Forum (2009) The Travel and Tourism Competitiveness Report 2009: Managing in a Time of Turbulence, Geneva.

World Economic Forum (2011) The Travel and Tourism Competitiveness Report 2011: Beyond the Downturn, Geneva.

World Economic Forum (2013) The Travel and Tourism Competitiveness Report 2013: Reducing Barriers to Economic Growth and Job Creation, Geneva.

World Economic Forum (WEF), www.weforum.org (28.1.2014.)

World Tourism Organization (UNWTO), www2.unwto.org (30.1.2014.)

\section{ANALIZA KULTURNIH RESURSA ZEMALJA JUGOISTOČNE EVROPE KAO FAKTORA KONKURENTNOSTI U TURIZMU}

Apstrakt: Nekadašnja uloga turizma u pogledu pružanja usluga smeštaja i ishrane je pevaziđena. Turistička ponuda sve više uključuju dodatne sadržaje kao što su posete raznim kulturnim dobrima, materijalnim i nematerijalnim i događajima koje turisti doživljavaju vizuelno. U savremenim turističkim kretanjima kulturni resursi zemalja Jugoistočne Evrope predstavljaju bitan faktor koji utiče na održanje konkurentnosti u uslovima sve veće konkurencije u svetskim razmerama. Kulturni resursi direktno utiču na turizam, ali javlja se i inverzan odnos uticaja turizma na kulturne resurse koji postaju važan činilac za izbor turističke destinacije. Predmet ovog rada jeste sagledavanje doprinosa kulturnih resursa razvoju turističke destinacije uz pomoć analize elemenata Indeksa konkurentnosti putovanja i turizma - TTCI (Travel and Tourism Competitiveness Index).

Ključne reči: kulturni resursi, konkurentnost, turizam, TTCI, zemlje Jugoistočne Evrope. 